\section{NEW RECORDS OF SHORT-NOSED FRUIT BAT CYNOPTERUS SPHINX (VAHL, 1797) FROM THAR DESERT, RAJASTHAN}

\author{
K.R. Senacha ${ }^{1}$, K.B. Vyas ${ }^{2}$ and Ashok Purohit ${ }^{2}$ \\ ${ }^{1}$ Bombay Natural History Society, Hornbill House, S.B.S. Raod \\ (Opp. Lion Gate), Mumbai, Maharashtra 400023, India \\ 2 Department of Zoology, J.N.V. University, Jodhpur, Rajasthan \\ 342001, India \\ Email: ${ }^{1}$ senacha@yahoo.com
}

plus web supplement of 1 page

The Short-nosed Fruit Bat Cynopterus sphinx is distributed widely in the Indian subcontinent and in south-east Asia. Within India it occurs commonly and is widespread (Bates \& Harrison, 1997; Molur et al., 2002). Although it has been reported from southern and southwestern Rajasthan (Sinha, 1980; Advani, 1982; Molur et al., 2002; Dookia, 2004), we could find no previous reference to its presence in the parts of northwestern Rajasthan. Recently, we recorded this species for the first time in Thar desert of Jaisalmer and Jodhpur districts of Rajasthan (Fig. 1).

During our survey from August to October 2004, in Jodhpur and Jaisalmer districts, we recorded two diurnal roosts of the Short-nosed Fruit Bat (Image $1^{\mathrm{w}}$ ). On 25 August 2004, two individuals (male \& female) were seen at Lathi village $\left(27.03661^{\circ} \mathrm{N}\right.$ $\& 71.51699^{\circ} \mathrm{E}$ ) of Jaisalmer district. They were found roosting in a semi-dark portion of a dilapidated fort of this village, along with three microchiropteran species, namely, Taphozous nudiventris, Rhinopoma microphyllum kinneari and $R$. hardwickii (Image $2^{\mathrm{w}}$ ).

The second roost was located on 5 October 2004, at Tinwari village $\left(26.46195^{\circ} \mathrm{N} \& 72.92123^{\circ} \mathrm{E}\right)$ of Jodhpur district. Four individuals (two pairs of male $\&$ female bats) were seen roosting in an abandoned building, Badi Haveli, along with four species of microchiropterans namely T. nudiventris, T. perforatus, $R$. microphyllum kinneari and $R$. hardwickii (Image $3^{\mathrm{w}}$ ). In each of these roosts we estimated more than 3000 individuals of all species.

All the six individuals of $C$. sphinx were caught by hoop net and morphometric measurements were taken (Table 1). We also analyzed their comparative response to our entry into the diurnal roosts. The Cynopterus sphinx looked more sensitive, but second to $T$. perforatus, to the disturbance caused by our visit, making frequent flights in the roost and looking more disturbed when lights were pointed at them. However, R. microphyllum kinneari, $R$. hardwickii and T. nudiventris roosting did not react strongly. Characteristically, they were roosting in close proximity, sometimes in contact with each other. C. sphinx seemed tolerant to the co-roosting individuals of other species and did not react strongly even when individuals of $T$. nudiventris exhibited aggression. At both the roosts they were occupying the ceiling, either the corners or wall edges.

From the Thar desert part of Rajasthan so far there is only one record of $C$. sphinx from Bhinmal $\left(25.00214^{\circ} \mathrm{N} \& 72.26257^{\circ} \mathrm{E}\right)$ in Jalor district (Dookia, 2004). Current findings add significantly to the distribution range of $C$. sphinx in the north-western parts of Rajasthan. Tinwari and Lathi are located $175 \mathrm{~km}$ north-east and $240 \mathrm{~km}$ north-west of Bhinmal, respectively (Fig. 1) and represent the characteristic habitat of the Thar desert.

Beside local range extension, the current findings add to the knowledge of roosting biology of $C$. sphinx. Although we have several references on biology of $C$. sphinx (Bates \& Harrison, 1997; Balasingh et al., 1993, 1995; Elangovan et al., 2000, 2001, 2003; Storz et al., 2000; Vasishta \& Badwaik, 1994), roosting association of this species with four microchiropterans, namely $R$. microphyllum kinneari, $R$. hardwickii, T. nudiventris and T. perforatus looks imperative, as we could find no previous reference to such roost making behaviour. Also, their roost in eaves of buildings is an uncommon sighting.

\section{REFERENCES}

Advani, R. (1982). Distribution and status of chiroptera species in Rajasthan, India. Saugertierkundliche Mitt. 30(1): 49-52.

Balasingh, J., S.S. Isaac and R. Subbaraj (1993). Tent-roosting by the frugivorous bat, Cynopterus sphinx (Vahl) in southern India. Current Science 65(5): 418 .

Balasingh, J., A. Koilraj and T.H. Kunz (1995). Tent construction by the short-nosed fruit bat Cynopterus sphinx (Chiroptera: Pteropodidae) in southern India. Ethology 100: 210-229.

Bates, P.J.J. and D.L. Harrison (1997). Bats of the Indian Subcontinent. Harrison Zoological Museum, 258pp.

Dookia, S. (2004). Occurrence of the short-nosed fruit bat (Cynopterus

${ }^{w}$ See Images 1-3 in the web supplement at www.zoosprint.org

Table 1. Morphometric measurements of the Cynopterus sphinx specimen collected from the fort of Lathi village in Jaisalmer

\begin{tabular}{|c|c|c|c|c|c|c|}
\hline \multirow[t]{4}{*}{ Name of the body part } & \multicolumn{5}{|c|}{ Length in $\mathrm{mm}$} & \\
\hline & \multicolumn{2}{|c|}{ Lathi village } & \multicolumn{4}{|c|}{ Tinwari village } \\
\hline & \multirow[t]{2}{*}{ Male $^{*}(n=1)$} & \multirow[t]{2}{*}{ Female $(n=1)$} & \multicolumn{2}{|c|}{ Male $(n=2)$} & \multicolumn{2}{|c|}{ Female $(n=2)$} \\
\hline & & & $n_{1}$ & $\mathrm{n}_{2}$ & & $\mathrm{n}_{2}$ \\
\hline HB (Head and Body length) & 100 & 102 & 98 & 103 & 108 & 105 \\
\hline $\mathrm{T}$ (Tail) & 17 & 16 & 15 & 17 & 18 & 17 \\
\hline HF (Hind Foot) & 16 & 16 & 14 & 17 & 17 & 16 \\
\hline FA (Fore Arm) & 71 & 72 & 68 & 73 & 75 & 73 \\
\hline$E($ ear) & 21 & 21 & 19 & 22 & 23 & 21 \\
\hline WS (Wing Span) & 342 & 358 & 340 & 365 & 378 & 362 \\
\hline TbL (Tibial length) & 34 & 35 & 32 & 35 & 35 & 34 \\
\hline
\end{tabular}

* The specimen of male Cynopterus sphinx is kept in the laboratory of Dr. Ashok Purohit, Department of Zoology, J.N.V. University, Jodhpur.

(C) Zoo Outreach Organisation; www.zoosprint.org Manuscript 1428; Received 03 September 2005; Revised received 14 July 2006; Finally accepted 20 August 2006 ; Date of publication 21 September 2006 


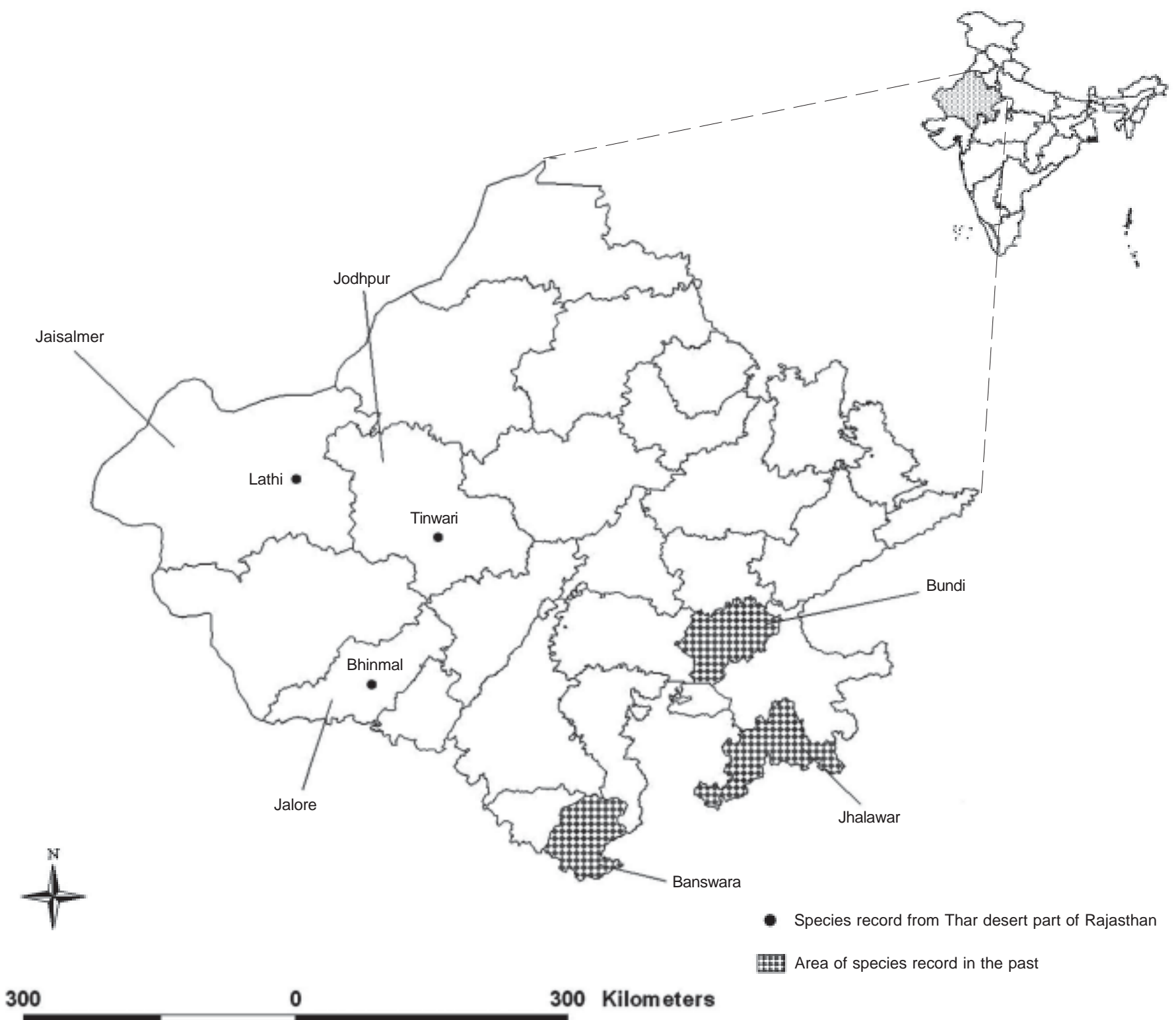

Figure 1. Distribution of Short-nosed Fruit Bat, Cynopterus sphinx in Rajasthan

sphinx Vahl, 1797) in the Thar desert of Rajasthan. Zoos' Print Journal 19(9): 1629 .

Elangovan, V., G. Marimuthu and T.H. Kunz (2000). Nectar feeding behaviour in the short-nosed fruit bat Cynopterus sphinx (Pteropodidae). Acta Chiropterologica 2: 1-5.

Elangovan, V., G. Marimuthu and T.H. Kunz (2001). Temporal pattern of resource use by the short-nosed fruit bat Cynopterus sphinx (Megachiroptera: Pteropodidae). Journal of Mammalogy 82:161-165. Elangovan, V., E.Y.S. Priya, H. Raghuram and G. Marimuthu (2003). Postnatal development in the short-nosed fruit bat (Cynopterus sphinx): growth rate and age estimation. Acta Chiropterologica 5: 107116.

Molur, S., G. Marimuthu, C. Srinivasulu, S. Mistry, A.M. Hutson, P.J.J. Bates, S. Walker, K. Padma Priya and A.R. Binu Priya (Eds.) (2002). Status of South Asian Chiroptera. Conservation Assessment and Management Plan (C.A.M.P.) Workshop Report. Zoo Outreach Organisation, CBSG South Asia and WILD, Coimbatore, viii+141 pp+CD-Rom.
Sinha, Y.P. (1980). Further observations on the field ecology of Rajasthan bats. Journal of the Bombay Natural History Society 77(3): 465-470.

Storz, J.F., J. Balasingh, P.T. Nathan, K. Emmanuel and T.H. Kunz (2000). Dispersion and site-fidelity in a tent-roosting population of the short-nosed fruit bat (Cynopterus sphinx) in southern India. Journal of Tropical Ecology 16: 117-131.

Vasishta, S.G. and N. Badwaik (1994). An unusual roost choice by the Indian short-nosed fruit bat, Cynopterus sphinx gangeticus (Anderson). Journal of the Bombay Natural History Society 91(3): 447.

\section{ACKNOWLedgement}

We thank the Department of Science and Technology, Government of India, for providing financial assistance to conduct this survey and are also grateful to Dr. Asad Rahmani, Director, Bombay Natural History Society for his academic support. 